Canadian

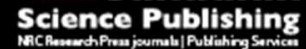

Canadian Journal of Microbiology Revue canadienne de de microbiologie

\title{
Virulence and antimicrobial susceptibility of clinical and environmental strains of Aeromonas spp. from Northeastern Brazil
}

\begin{tabular}{|r|l|}
\hline Journal: & Canadian Journal of Microbiology \\
\hline Manuscript ID: & cjm-2015-0107.R2 \\
\hline Manuscript Type: & Article \\
\hline Date Submitted by the Author: & $21-$ May-2015 \\
\hline Complete List of Authors: & $\begin{array}{l}\text { Castelo-Branco, Débora; Federal University of Ceará Fortaleza, Brazil, } \\
\text { Guedes, Glaucia; Federal University of Ceará, } \\
\text { Brilhante, Raimunda; Federal University of Ceará, } \\
\text { Marcos F., Rocha; State University of Ceará, } \\
\text { Sidrim, José; State University of Ceará, } \\
\text { Moreira, José; Federal University of Ceará, } \\
\text { Cordeiro, Rossana; Federal University of Ceará, } \\
\text { Sales, Jamille; State University of Ceará, } \\
\text { Riello, Giovanna; Federal University of Ceará, } \\
\text { Alencar, Lucas; State University of Ceará, } \\
\text { Araujo-Neto, Manoel; State University of Ceará, } \\
\text { Vasconcelos, David; Federal University of Ceará, } \\
\text { Bezerra de Menezes, Isis; Federal University of Ceará, } \\
\text { Ponte, Yago; State University of Ceará, } \\
\text { Sampaio, Celia; State University of Ceará, } \\
\text { Monteiro, André; Department of Statics, Federal University of Cear } \\
\text { Bandeira, Tereza; DASA, }\end{array}$ \\
\hline \multirow{2}{*}{ Keyword: } & $\begin{array}{l}\text { Aeromonas spp., humans infections, environments, virulence genes, } \\
\text { antimicrobial resistance }\end{array}$ \\
\hline \hline
\end{tabular}

\section{SCHOLARONE \\ Manuscripts}


1 Version 4 - Note - Canadian Journal of Microbiology

2 Virulence and antimicrobial susceptibility of clinical and environmental strains of

3

4

5

6

7

8

9

10

11

12
Aeromonas spp. from Northeastern Brazil

Débora de Souza Collares Maia Castelo-Branco ${ }^{a}$, Glaucia Morgana de Melo Guedes ${ }^{\mathrm{a}}$, Raimunda Sâmia Nogueira Brilhante ${ }^{\mathrm{a} *}$, Marcos Fábio Gadelha Rocha ${ }^{\mathrm{a}, \mathrm{b}}$, José Júlio Costa

Sidrim $^{\mathrm{a}}$, José Luciano Bezerra Moreira ${ }^{\mathrm{a}}$, Rossana de Aguiar Cordeiro ${ }^{\mathrm{a}}$, Jamille Alencar Sales ${ }^{\mathrm{b}}$, Giovanna Riello Barbosa ${ }^{\mathrm{a}}$, Lucas Pereira de Alencar ${ }^{\mathrm{b}}$, Manoel de Araújo Neto Paiva ${ }^{\mathrm{b}}$, David Caldas Vasconcelos ${ }^{\mathrm{c}}$, Isis Sousa Bezerra de Menezes ${ }^{\mathrm{a}}$, Yago Brito de Ponte ${ }^{\mathrm{b}}$, Célia Maria de Souza Sampaio ${ }^{\mathrm{b}}$, André Jalles Monteiro ${ }^{\mathrm{d}} \&$ Tereza de Jesus Pinheiro Gomes Bandeira ${ }^{\mathrm{a}, \mathrm{e}, \mathrm{f}}$

${ }^{\mathrm{a}}$ Department of Pathology and Legal Medicine, Posgraduate Program in Medical

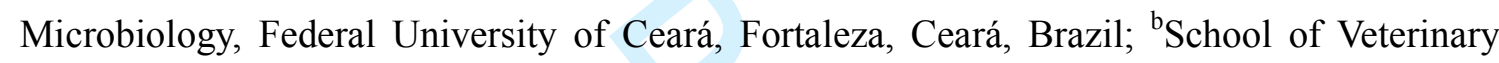
Medicine, Posgraduate Program in Veterinary Sciences, State University of Ceará, Fortaleza, Ceará, Brazil; ${ }^{\mathrm{c}}$ Department of Pathology and Legal Medicine, Posgraduate Program in Medical Sciences, Federal University of Ceará, Fortaleza, Ceará, Brazil; ${ }^{\mathrm{d}}$ Department of Statistics and Applied Mathematics, Federal University of Ceará, Fortaleza, Ceará, Brazil; ${ }^{\mathrm{e}}$ School of Medicine, Christus College - Unichristus, Fortaleza, Ceará, Brazil; ${ }^{\mathrm{f} D A S A}$, Fortaleza, Ceará, Brazil.

*Corresponding author: Raimunda Sâmia Nogueira Brilhante.Rua Barão de Canindé, 210; Montese. CEP: 60.425-540. Fortaleza, CE, Brazil. Tel: +55 853366 8319; e-mail: brilhante@ufc.br. 


\section{Abstract}

This study aimed at isolating and identifying clinical and environmental strains of Aeromonas spp., through biochemical tests and the automated method VITEK 2, and by investigating the presence of the virulence genes cytotoxic enterotoxin (act), haemolysin (asal) and type III secretion system (ascV) and the in vitro antimicrobial susceptibility. From the clinical isolates, 19 A. hydrophila, 3 A. veronii bv. sobria and 1 A. caviae were identified, while from the environmental strains, 11 A. hydrophila, 22 A. veronii bv. sobria, 1 A. veronii bv. veronii and $1 \mathrm{~A}$. caviae were recovered. The gene act was detected in $69.5 \%$, while asalwas detected in $8.6 \%$ and $a s c V$ in $34.7 \%$ of the clinical isolates. As for the environmental strains, the detection rates were $51.4 \%, 45.7 \%$ and $54.2 \%$ for the genes act, asal and ascV, respectively. Resistance to amoxicillin-clavulanate and piperacillin-tazobactam was observed in 15 and 3 clinical strains, respectively, and resistance to ceftazidime, meropenem, imipenem, ciprofloxacin and trimethoprim-sulfamethoxazole was observed in one strain for each drug. Resistance to amoxicillin-clavulanate and piperacillin-tazobactam was detected in 17 and 1 environmental strain, respectively. Higher resistance percentages were observed in clinical strains, but environmental strains also showed this phenomenon and presented a higher detection rate of virulence genes. Thus, it is important to monitor the antimicrobial susceptibility and pathogenic potential of the environmental isolates.

Keywords: Aeromonas spp;; human infections; environments; virulence genes; antimicrobial resistance. 
44

45

The species of the genus Aeromonas are facultative anaerobic, oxidase-positive, glucose fermenters Gram-negative bacilli (Winn et al. 2006). They are more frequently found in aquatic environments, such as public water supplies, rivers, lakes and estuaries. The isolation of the microorganism from human food such as fish and shellfish has also been described (Janda and Abbott 2010).

The pathogenic potential of Aeromonas spp. has been related to several virulence factors that allow colonization, immune evasion and proliferation in the host. Among these factors, researchers have mentioned the presence of cytotoxic enterotoxin, cytotonic enterotoxin, proteases, hemolysins and products of the type III secretion system (BeazHidalgo et al. 2013; Igbinosa et al. 2012). Aeromonas spp. infections usually occur after the consumption of contaminated food and water or after traumatic lesions (Janda and Abbott 2010).

In general, most strains present in vitro susceptibility to aminoglycosides, third and fourth generation cephalosporins, carbapenems, quinolones and sulfamethoxazoletrimethoprim, but cases of resistance have been described (Chao et al. 2013, Chuang et al. 2011). In addition, Aeromonas spp. are intrinsically resistant to penicillins and present high resistance levels to first and second generation cephalosporins (Janda and Abbott 2010; Senderovich et al. 2012).

The wide number of sources from which Aeromonas can be recovered contribute to the constant exposure of human beings to these bacteria, reinforcing the importance of performing environmental monitoring. Thus, the present study aimed at isolating clinical and environmental strains of Aeromonas spp. and investigating the presence of virulence genes and the antimicrobial susceptibility of the tested strains.

The clinical strains used in this study were obtained from the collection of the clinical microbiology laboratory of DASA, in Fortaleza, Ceará Brazil. The strains of Aeromonas spp 
were recovered during 2012 and 2013, from clinical specimens obtained from patients with different types of infections, such as sepsis, hepatobiliary diseases, skin and soft tissue infection. These strains were kindly provided for our study by the trustee of DASA. This period called our attention because of the higher prevalence of infections with this bacterial genus, when compared to previous years. The number of cases diagnosed during the surveyed years (2012-2013) was twice higher than the number of cases diagnosed during the years of $2010-2011$.

Environmental strains were recovered from water samples collected from Sapiranga Lake ( $3^{\circ} 48^{\prime} 46^{\prime \prime} \mathrm{S}$ and $\left.38^{\circ} 27^{\prime} 30.83^{\prime \prime} \mathrm{W}\right)$, city of Fortaleza, Ceará, and from the digestive tracts of prawns and fish collected in this lake. In addition, water samples from prawn (Macrobrachium amazonicum) farming were also used for the recovery of Aeromonas sp. These samples were collected weekly from tanks, during two consecutive hatchery cycles at the Laboratory of Crustacean Culture of the State University of Ceará.

Environmental water samples $(5 \mathrm{~mL})$ were collected from shallow areas of Sapiranga Lake, while those from prawn farming tanks were collected from three areas: surface, substrate and water filter. Two samples of lake water and eighteen samples of hatchery water were processed in duplicate, in two tubes containing $2500 \mu \mathrm{L}$. The tubes were centrifuged at $3000 \mathrm{rpm}$, for 20 minutes. Then, $2000 \mu \mathrm{L}$ of the supernatant were discarded and the remaining volume of the tubes was homogenized, followed by the addition of sterile saline to reach a final volume of $2000 \mu \mathrm{L}$. The solution was homogenized by vortexing, and allowed to settle at $25{ }^{\circ} \mathrm{C}$, for 30 minutes (Medeiros et al. 2008). Thereafter, $10-\mu \mathrm{L}$-aliquots of the supernatant from each sample were seeded on the culture media.

The prawns and fish were collected in fish nets. To collect the digestive tracts, 10 prawns were pooled as a single sample, with a total of two samples. Three fish were collected and each fish was considered as one single sample. The digestive tracts were removed by a 
transversal cut, and the content was processed as described by (Brilhante et al. 2011).

The study was previously approved by the Chico Mendes Institute for Conservation of Biodiversity/Biodiversity Authorization and Information System -SISBIO, under the number 28175-1.

For the primary isolation, the clinical samples were inoculated on blood agar and Chromogenic chromID CPS medium (bioMeriéux, França), which are commonly used in the clinical microbiology laboratory. Environmental samples were plated on MacConkey agar (Difco, USA). The plates were incubated at $35^{\circ} \mathrm{C}$, for up to 48 hours. Subsequently, the phenotypical characteristics of the colonies were observed and lactose negative colonies were selected.

Gram-negative isolates that tested positive for cytochrome oxidase, glucose fermentation, urease and indole production were classified as Aeromonas sp. (Winn et al. 2006). Aeromonas species were identified through the automated method Vitek 2 Compact ${ }^{\circledR}$, according to the manufacturer's protocol (bioMérieuxInc, Durham, NC, USA), and only results with probability level above 93\% were considered reliable (Tang et al. 2014). After automated identification, the Voges-Proskauer test was included to differentiate between $A$. hydrophila and A. caviae. For the quality control of the conventional biochemical tests, Escherichia coli ATCC ${ }^{\circledR} 25922$ and Pseudomonas aeruginosa ATCC® 27853 were included in the assays.

DNA extraction was performed using the Wizard ${ }^{\circledR}$ Genomic DNA purification kit (Promega USA). The concentration and purity of DNA were measured with a Qubit ${ }^{\circledR}$ spectrophotometer (Invitrogen, Carlsbad, USA). Primers for the amplification of the assessed virulence genes were designed based on previous studies. In order to detect the coding genes for cytotoxic enterotoxin (act), hemolysin (asa-l) and type III secretion system (ascV), the following primers were used: (5'-3') act_F- AGAAGGTGACCACCAAGAACA and act_R- 

AACTGACATCGGCCTTGAACTC
(Kingombe et
al. 1999); asa-1_F-

TAAAGGGAAATAATGACGGCG and $a s a_{-}{ }_{-}$R- GGCTGTAGGTATCGGTTTTCG (Wang et al. 2003); and ascV_F- CTCGAACTGGAAGAGCAGAATG and ascV_RGAACATCTGGCTCTCCTTCTCGATG (Martino et al. 2011). The reaction was conducted in a final volume of $25 \mu \mathrm{L}$, under the PCR conditions described by Martino et al. (2011).

The products for act (232bp; Kingombe et al. 1999), asa-1 (249bp; Wang et al. 2003) and ascV (577bp; Martino et al. 2011) were analyzed through electrophoresis in $1.8 \%$ agarose gel, using an intercalating fluorescent loading dye, and visualized on an UV transluminator (Hu et al. 2012; Martino et al. 2011; Ottaviani et al. 2011). A previously identified strain of $A$. hydrophila, which was positive for the presence of the three tested virulence genes, was used as positive control in each of the performed PCR assays, during this research. Additionally the mix without DNA was used as negative control of reaction.

The tested antimicrobial drugs and their respective concentration ranges were selected based on the document M45-A2 from Clinical and Laboratory Standards Institute (CLSI, 2010) and the following drugs were included: amoxicillin-clavulanate (AMC), piperacillintazobactam (PTZ), ceftazidime (CAZ), cefepime (FEP), meropenem (MEM), imipenem (IPM), gentamicin (GN), ciprofloxacin (CIP) and trimethoprim-sulfamethoxazole (SXT) (Sigma-Aldrich Corporation, USA). The tests were carried out by the broth microdilution method as standardized by CLSI,document M07-A09 (CLSI 2012), in Mueller-Hinton broth (Difco, USA) and final bacterial inocula of $5 \times 10^{5} \mathrm{UFC} / \mathrm{mL}$ were used (CLSI 2010).

The plates were read after $18-20 \mathrm{~h}$ of incubation at $35^{\circ} \mathrm{C}$. The minimum inhibitory concentration (MIC) was defined as the lowest concentration able to inhibit $100 \%$ of growth, except for trimethoprim-sulfamethoxazole, for which the MIC was defined as the lowest concentration capable of inhibiting $80 \%$ of bacterial growth (CLSI 2012), when compared to the growth of the control. The results were interpreted according to the document M45-A2 
144 (CLSI 2010) and the interpretive criteria were: $\mathrm{S} \leq 8 / 4, \mathrm{I}=16 / 8$ and $\mathrm{R} \geq 32 / 16 \mu \mathrm{g} / \mathrm{mL}$ for $\mathrm{AMC}$; $145 \mathrm{~S} \leq 16 / 4, \mathrm{I}=32 / 4-64 / 4, \mathrm{R} \geq 128 / 4 \mu \mathrm{g} / \mathrm{mL}$ for $\mathrm{PTZ} ; \mathrm{S} \leq 4, \mathrm{I}=8, \mathrm{R} \geq 16 \mu \mathrm{g} / \mathrm{mL}$ for $\mathrm{CAZ} ; \mathrm{S} \leq 8, \mathrm{I}=16$, $146 \mathrm{R} \geq 32 \mu \mathrm{g} / \mathrm{mL}$ for $\mathrm{FEP} ; \mathrm{S} \leq 4, \mathrm{I}=8, \mathrm{R} \geq 16 \mu \mathrm{g} / \mathrm{mL}$ for $\mathrm{MEM} ; \mathrm{S} \leq 4, \mathrm{I}=8, \mathrm{R} \geq 16 \mu \mathrm{g} / \mathrm{mL}$ for IPM; $147 \mathrm{~S} \leq 4, \mathrm{I}=8, \mathrm{R} \geq 16 \mu \mathrm{g} / \mathrm{mL}$ for $\mathrm{GN} ; \mathrm{S} \leq 1, \mathrm{I}=2, \mathrm{R} \geq 4 \mu \mathrm{g} / \mathrm{mL}$ for $\mathrm{CIP}$ and $\mathrm{S} \leq 2 / 38$ and $\mathrm{R} \geq 4 / 76 \mu \mathrm{g} / \mathrm{mL}$ for SXT. Escherichia coli ATCC ${ }^{\circledR}-35218$ and E. coli ATCC®-25922 were included as control strains (M100-S22, CLSI, 2012).

In order to analyze the MIC differences between species, origin (clinical or environmental strains), MIC values were submitted to Log2-tranformation to analyze the number of dilutions, through a linear model. In addition, Pearson's Chi square test and Fisher's exact test were used in order to compare categorical data between species and origin and species and the presence of virulence genes. P-values lower than 0.05 indicated significant 155 results.

Overall, 23 clinical isolates were obtained and identified as $A$. hydrophila $(\mathrm{n}=19), A$. veronii. bv. sobria $(\mathrm{n}=3)$ and $A$. caviae $(\mathrm{n}=1)$. The greatest number of isolates were obtained from blood samples (12/23), followed by liquid from the abdominal cavity $(5 / 23)$, wounds (4/23), abdominal tissue (1/23) and urine (1/23). From the environmental samples, 35 isolates were obtained and identified as A. hydrophila $(\mathrm{n}=11)$, A. veronii bv. sobria $(\mathrm{n}=22)$, A veronii bv. veronii $(\mathrm{n}=1)$ and $A$. caviae $(\mathrm{n}=1)$. These strains were recovered from the digestive tract of fish (3/35) and prawns (4/35), and from pond (7/35) and larviculture water (21/35; Table 1$)$. isolates, while more than one virulence gene was observed in $21.7 \%(5 / 23)$. The act gene was the most common in these isolates $(11 / 15 ; 9$ A. hydrophila, 1 A. veronii bv. sobria and $1 A$ 
$169(\mathrm{P}=0.0173)$ and $\operatorname{asc} V(\mathrm{P}=0.001)$ genes were more present in clinical strains of $A$. hydrophila, 170 when compared to environmental isolates, and the combination of these genes was the most 171 commonly observed combination among clinical strains (3/5 strains: 2 A. hydrophila, 1 A. 172 veronii bv. veronii). Only one strain of $A$. veronii bv. sobria presented all the studied virulence 173 genes (Table 1).

As for the environmental strains, the presence of only one virulence gene was observed in $25.7 \%(9 / 35)$ of the strains, whereas $51.4 \%(18 / 35)$ had more than one gene. The act gene alone was detected in three strains ( 2 A. veronii bv. sobria; 1 A. hydrophila), while 177 the asc $V$ gene was detected in six strains of $A$. hydrophila. In environmental strains, combinations were observed between act and $\operatorname{asa}_{-1}$ (5/18), asa- and $a s c V$ (3/18), act and ascv (2/18), only in A. veronii bv. veronii. In addition, eight strains showed all the virulence genes (6 A. veronii bv. sobria; 1 A. caviae; 1 A.hydrophila; Table 1). observed in 35 isolates: $15 / 23$ clinical strains $(\mathrm{MIC}=32 / 16 \mu \mathrm{g} / \mathrm{mL})$ and $17 / 35$ environmental strains (MIC $\geq 32 / 16 \mu \mathrm{g} / \mathrm{mL}$ ). Piperacillin-tazobactam resistance was observed in three clinical strains (MIC $\geq 128 / 4 \mu \mathrm{g} / \mathrm{mL}$ ) and one environmental strain ( $\mathrm{MIC}=128 / 4 \mu \mathrm{g} / \mathrm{mL})$. Resistance to ceftazidime $(\mathrm{MIC}=64 \mu \mathrm{g} / \mathrm{mL})$, meropenem $(\mathrm{MIC}=16 \mu \mathrm{g} / \mathrm{mL})$, imipenem $(\mathrm{MIC}=32 \mu \mathrm{g} / \mathrm{mL})$, ciprofloxacin $(\mathrm{MIC}=64 \mu \mathrm{g} / \mathrm{mL})$ and trimethoprim-sulfamethoxazole $(\mathrm{MIC}=16 / 304 \mu \mathrm{g} / \mathrm{mL})$ was observed in one different clinical strain for each antimicrobial drug. Imipenem $(\mathrm{P}=0.0001)$, meropenem $(\mathrm{P}=0.0381)$ and ciprofloxacin $(\mathrm{P}=0.0169)$ had higher MICs against

A. hydrophila, when compared to A. veronii. Furthermore, intermediate susceptibility to amoxicillin-clavulanate, piperacillin-tazobactam, imipenem and gentamicin was also observed among clinical and environmental strains (Table 2).

Finally, the MIC values of amoxicillin-clavulanate $(\mathrm{P}=0.00149)$, piperacillintazobactam $(\mathrm{P}=0.0399)$, imipenem $(\mathrm{P}=0.00415)$ and meropenem $(\mathrm{P}=0.0399)$ increased in the 
194

195

196

197

presence of the genes $a s a_{-1}, a c t$, asc $V$ and $a s c V$, respectively.

Aeromonas spp. have been considered emerging infectious agents, particularly in immunocompromised individuals (Parker and Shaw 2011). The prevalence of infections with these microorganisms is most likely underestimated, as it is not a mandatory reportable condition in most countries, and it varies greatly according to the geographic region and the type of infection (Janda and Abbott, 2010). Bacteremia, for example, is a common type of infection caused by these microorganisms, representing 30 to $55 \%$ of the cases (Chuang et al. 2011; Tang et al. 2014). Similar results were obtained in the present study, since $52 \%$ of the clinical isolates were recovered from blood samples.

There are several pathways through which humans become colonized/infected with Aeromonas species. Aeromonas spp. can be isolated from several sources, including aquatic habitats, invertebrates (ticks and insects), fish, birds, and soils. The ingestion of contaminated water and food is the main pathway of infection, but other routes include recreational activities, such as diving, especially, if there is loss of skin integrity (Janda and Abbott 2010). The risk of infection in people should also be considered when handling animals, mainly prawns and fish (Kao and Kao 2012).

These data reinforce the importance of environmental monitoring to better understand the pathogenic potential and antimicrobial susceptibility of Aeromonas strains. The most frequent species were $A$. veronii bv. sobria $(62.8 \%)$, followed by $A$. hydrophila (31.4\%). In a previous study, A. hydrophila and A.veronii bv sobria were among the most frequently isolated species from water samples (Ottaviani et al. 2011), which have also been described as important human pathogens (Chao et al. 2013; Tang et al. 2014).

All Aeromonas isolates recovered in the present study were identified through manual phenotypical tests, for the initial screening, followed by automated analyses, through the Vitek 2 system, which led to the identification of the species with a high probability 
219 (above 93\%). An additional test was performed (Voges Proskauer), in order to differentiate $A$.

220 hydrophila from $A$. caviae. It is important to emphasize that commercial systems are capable

221 of correctly identifying A. hydrophila, A. veronii and A. caviae (Janda and Abbott, 2010).

222

We also investigated the presence of virulence genes in clinical and environmental

223

224

strains of Aeromonas spp. Combination of all genes was less frequently found in clinical strains $(1 / 23)$, when compared to environmental ones $(8 / 35)$, corroborating the findings of Ottaviani et al. (2011), who observed that environmental strains have a higher number of virulence genes than clinical strains. These data show that the distribution of virulence genes among Aeromonas is not uniform, demonstrating that virulence may vary among species of this genus and among strains of the same species (Aravena-Róman et al. 2014; Yano et al. 2015).

Antimicrobial resistance was more commnly observed among clinical isolates, when compared to environmental ones, as previously described (Aravena-Román et al. 2012). The clinical strains were resistant to seven of the nine tested drugs, while in the environmental strains resistance to two antimicrobials was observed. In addition, results of intermediate susceptibility observed in clinical and environmental strains are an alert for the potential emergence of antimicrobial resistant strains in Aeromonas spp. (Souza et al. 2010).

Amoxicillin-clavulanate and piperacillin-tazobactam presented a higher rate of resistance and were the only drugs to which both clinical and environmental strains were resistant. The production of $\beta$-lactamases has been described as the main cause of resistance among Aeromonas and some of these bacterial enzymes are not inhibited by $\beta$-lactamase inhibitors, such as clavulanic acid, tazobactam, and sulbactam (Chen et al. 2012; Senderovich et al. 2012).

Despite having observed a higher percentage of resistance in clinical strains, environmental strains also showed this phenomenon. In addition, virulence genes were 
244 detected in strains of both origins. It is known that exposure to environmental sources (aquatic

245 habitats, soils, animals), as well as the consumption of contaminated food and water, may

246 represent a risk to human health. Hence, considering the ubiquity of Aeromonas spp.,

247 contributing to their constant interaction with humans, and the detection of decreased

248 antimicrobial suscebtibility and virulence genes among environmental strains, it is important

249 to monitor the antimicrobial susceptibility and pathogenic potential of the environmental 250 isolates.

\section{Funding}

This work supported by grants from the National Council for Scientific and

254

255

256

257

258

259

260

261

262

263

264

265

266

\section{References}

Aravena-Román, M., Inglis, T.J.J., Henderson, B., Rilley, T.V., and Chang, B.J. 2012. Antimicrobial Susceptibilities of Aeromonas Strains Isolated from Clinical and Environmental Sources to 26 Antimicrobial Agents. Antimicrob. Agents Chemoter. 569(2): 11101112.doi:10.1128/AAC.05387-11. PMID:22123695.

Aravena-Román, M., Inglis, T.J.J., Riley, T.V., and Chang, B.J. 2014. Distribution of 13 Virulence Genes among Clinical and Environmental Aeromonas spp .in Western Australia. Eur. J. Clin. Microbiol. Infect. Dis. 33(11):1889-1895.doi10.1007/s10096-014-21570.PMID:24859908. 
267 Beaz-Hidalgo, R., and Figueras, M.J. 2013. Aeromonas spp. whole genomes and virulence 268 factors implicated in fish disease. J. Fish Dis. 36(4): 371-388.doi:10.1111/jfd.12025. 269 PMID:23305319.

270 Brilhante, R.S.N., Paiva, M.A.N., Sampaio, C.M.S., Teixeira, C.E., Castelo-Branco, 271 D.S., Leite, et al. Yeasts from Macrobrachium amazonicum: a focus on antifungal 272 susceptibility and virulence factors of Candida spp. FEMS Microbiol. Ecol. 76(2): 268273 77.doi:10.1111/j.1574-6941.2011.01050.x. PMID: 21241340.

274 Chao, C.M., Lai, C.C., Tang, H.J., Ko, W.C,. and Hsueh, P.R. 2013.Biliary tract infections 275 caused by Aeromonas species. Eur. J. Clin. Microbiol. Infect. Dis.32(2): 245276 251.doi:10.1007/s10096-012-1736-1. PMID: 22918516.

277 Chen, P.L., Ko, W.C., and Wu, C.J. 2012. Complexity of ß-lactamases among clinical 278 Aeromonas isolates and its clinical implications. J. Microbiol. Immunol. Infect. 45(6): 398279 403. doi:10.1016/j.jmii.2012.08.008. PMID: 23031536.

280 Chuang, H.C., Ho, Y.H., Lay, C.J., Wang, L.S., Tsai, Y.S., and Tsai, C.C. 2011. Different 281 Clinical Characteristics Among Aeromonas hydrophila, Aeromonas veronii biovar sobria and 282 Aeromonas caviae Monomicrobial Bacteremia. J. Korean. Med. Sci. 26(11): 1415283 1420.doi:10.3346/jkms.2011.26.11.1415. PMID:22065896.

284

CLSI. Methods for Antimicrobial Dilution and Disk Susceptibility Testing of Infrequently 285 Isolated or Fastidious Bacteria. CSLI document M45-A2. Wayne, PA: Clinical and Laboratory 286 Standards Institute; 2010.

287 CLSI. Methods for Dilution Antimicrobial Susceptibility Tests for Bacteria That Grow 288 Aerobically. CLSI document M07-A9. Wayne, PA: Clinical and Laboratory Standards 289 Institute; 2012. 
290

291

292

293

294

295

296

297

298

299

300

301

302

303

304

305

306

307

308

309

310

311

312

313

314

CLSI. Perfomance Standards for Antimicrobial Susceptibility Testing; Twenty-second

Informational Supplement. CLSI document M100-S22. Wayne, PA: Clinical and Laboratory Standards Institute; 2012.

Hu, M., Wang, N., Pan, Z.H., Lu, C.P, Liu, Y.J. 2012. Identity and virulence properties of Aeromonas isolates from diseased fish, healthy controls and water environment in China. Lett Appl Microbiol. 55(3): 224-233. doi: 10.1111/j.1472-765X.2012.03281.x. PMID: 22725694.

Igbinosa, I.H., Igumbor, E.U., Tom, F.A.M., and Okoh, A.I. 2012. Emerging AeromonasSpecies Infections and Their Significance in Public Health. ScientificWorld Journal 2012(2012):1-13.doi:10.1100/2012/625023. PMID:22701365.

Janda J.M., and Abbott S.L. 2010.The genus Aeromonas: Taxonomy, pathogenicity, and infection. Clin. Microbiol. Rev. 23(1): 35-73. doi:10.1128/CMR.00039-09. PMID: 20065325.

Kao, T.L., and Kao, M.L.2012. A fatal case of necrotizing Aeromonas schubertii fasciitis after penetrating injury. Amer. J. of Emergency Medicine. 30(1): 258.e3258.e5. doi:10.1016/j.ajem.2010.10.028. PMID: 21247722.

Kingombe, C.E., Huys, G., Tonolla, M., Albert, M.J., Swings, J., Peduzzi, R., et al. 1999. PCR detection, characterization, and distribution of virulence genes in Aeromonas spp. Appl. Environ. Microbiol. 65(12): 5293-5302.PMID:10583979.

Martino, M.E., Fasolato, L., Montemurro, F., Rosteghin, M., Manfrin, A., Patarnello, T, et al. 2011. Determination of Microbial Diversity of Aeromonas Strains on the Basis of Multilocus Sequence Typing, Phenotype, and Presence of Putative Virulence Genes. Appl. Environ. Microbiol. 77(14): 4986-5000.doi:10.1128/AEM.00708-11. PMID: 21642403.

Medeiros, A.O., Kohler, L.M., Hamdan, J.S., Missagia, B.S.,Barbosa, F.A., and Rosa, C.A. 2008. Diversity and antifungal susceptibility of yeasts from tropical freshwater environments in Southeastern Brazil. Water Res. 42(14): 3921-29. doi:10.1016/j.watres.2008.05.026. PMID: 18678387. 
315 Ottaviani, D., Parlani, C., Citterio, B., Masini, L., Leoni, F., Canonico, C., et al. 2011.

316 Putative virulence properties of Aeromonas strains isolated from food, environmental and

317 clinical sources in Italy: A comparative study. Int. J. Food Microbiol. 144(3): 538-545. 318 doi:10.1016/j.ijfoodmicro.2010.11.020. PMID:21138783.

319 Parker, J.L., and Shaw, J.G. 2011. Aeromonas spp. Clinical microbiology and disease. J. 320 Infect. 62(8): 09-11. doi:10.1016/j.jinf.2010.12.003. PMID: 21163298.

321 Senderovich, Y., Ken-Dror, S., Vainblat, I., Blau, D., Izhaki, I., and Halpern, M. A. 2012. 322 Molecular Study on the Prevalence and Virulence Potential of Aeromonas spp. Recovered 323 from Patients Suffering from Diarrhea in Israel. Plos One. 7(2): e30070. 324 doi:10.1371/journal.pone.0030070. PMID: 22355306.

Souza, C.O., Ramos, F.L.P, Mota, C.M., Santos, L.V.S., Lopes, M.L. 2010. Resistência antimicrobiana de Salmonella Typhi identificadas no Estado do Pará, Brasil. Rev PanAmazônica de Saude, 1(2):61-65. doi:10.5123/S2176-62232010000200007.

Tang, H.J., Lai, C.C., Lin, H.L., and Chao, C.M. 2014.Clinical Manifestations of Bacteremia 329 Caused by Aeromonas Species in Southern Taiwan. Plos One 9(3): e91642.doi: 330 10.1371/journal.pone.0091642. PMID: 24614100.

331 Wang, G., Clark, C.G., Liu, C., Pucknell, C., Munro, C.K., Kruk, T.M.A.C., et al. 332 2003.Detection and characterization of the hemolysin genes in Aeromonas hydrophila and 333 Aeromonas sobria by multiplex PCR. J. Clin. Microbiol. 41 (3): 1048334 54.doi:10.1128/JCM.41.3.1048-1054.2003. PMID: 12624028.

335 Winn, W.C., Allen, S.D., Janda, W.M., Koneman, E.W., Procop, G.W., Schreckenberger, P.C. 336 et al. 2006. Koneman's Color Atlas and Textbook of Diagnostic Microbiology. Baltimore, 337 MD: Lippincott Williams \& Wilkins.

338 Yano, Y., Hamano, K., Tsutsui, I., Aue-Umneoy, D., Ban, M., and Satomi, M. 2015. 339 Occurrence, molecular characterization, and antimicrobial susceptibility of Aeromonas spp. in 
340 marine species of shrimps cultured at inland low salinity ponds. Food Microbiol.47:21-27.

341 doi:10.1016/j.fm.2014.11.003.PMID:25583334.

342 
Table 1. Aeromonas spp. isolated from clinical and environmental samples and the frequency of virulence genes detection

\begin{tabular}{|c|c|c|c|c|c|c|c|c|c|c|}
\hline \multirow{2}{*}{ ORIGIN } & \multirow{2}{*}{ SITE } & \multirow{2}{*}{ SPECIES } & \multicolumn{8}{|c|}{ GENE } \\
\hline & & & act & $a s a_{-1}$ & ascV & $a c t+a s a_{-1}$ & $a c t+a s c V$ & $a s a_{-1}+a s c V$ & $a c t+a s a_{-1}+a s c V$ & None \\
\hline \multirow{3}{*}{ Clinical } & \multirow{3}{*}{ Blood } & A. hydrophila $(\mathrm{n}=10)$ & 3 & - & 4 & - & 2 & - & - & 1 \\
\hline & & A. veronii bv. sobria $(\mathrm{n}=1)$ & - & - & - & - & - & - & 1 & - \\
\hline & & A. caviae $(\mathrm{n}=1)$ & 1 & - & - & - & - & - & - & - \\
\hline \multirow[t]{2}{*}{ Clinical } & \multirow{2}{*}{ Wound } & A. hydrophila $(\mathrm{n}=2)$ & 1 & - & - & 1 & - & - & - & - \\
\hline & & A. veronii bv. sobria $(\mathrm{n}=2)$ & 1 & - & - & - & 1 & & - & - \\
\hline Clinical & Intra-abdominal liquid & A. hydrophila $(\mathrm{n}=5)$ & 4 & - & - & - & - & - & - & 1 \\
\hline Clinical & Abdominal tissue & A. hydrophila $(\mathrm{n}=1)$ & 1 & - & - & - & - & - & - & - \\
\hline \multirow[t]{2}{*}{ Clinical } & Urine & A. hydrophila $(\mathrm{n}=1)$ & - & - & - & - & - & - & - & 1 \\
\hline & \multirow[t]{2}{*}{ Subtotal } & $\mathrm{n}=23$ & $11 / 23$ & $0 / 23$ & $4 / 23$ & $1 / 23$ & $3 / 23$ & $0 / 23$ & $1 / 23$ & $3 / 23$ \\
\hline \multirow{4}{*}{ Environmental } & & A. hydrophila $(\mathrm{n}=10)$ & 1 & & 6 & - & - & - & - & 3 \\
\hline & \multirow{3}{*}{ Larviculture water } & A. veronii bv. sobria $(\mathrm{n}=9)$ & 1 & - & - & 3 & 2 & 2 & 1 & - \\
\hline & & A. veronii bv. veronii $(\mathrm{n}=1)$ & - & - & - & - & - & - & - & 1 \\
\hline & & A. caviae $(\mathrm{n}=1)$ & - & - & - & - & - & - & 1 & - \\
\hline \multirow[t]{2}{*}{ Environmental } & \multirow{2}{*}{ Pondwater } & A. hydrophila $(\mathrm{n}=1)$ & - & - & - & - & - & - & 1 & - \\
\hline & & A. veronii bv. sobria $(\mathrm{n}=6)$ & - & - & - & 2 & & 1 & 2 & 1 \\
\hline Environmental & Shrimpdigestivetract & A. veronii bv. sobria $(\mathrm{n}=4)$ & 1 & - & - & - & - & - & - & 3 \\
\hline Environmental & Fish digestive tract & A. veronii bv. sobria $(\mathrm{n}=3)$ & - & - & - & - & - & - & 3 & - \\
\hline & Subtotal & $\mathrm{n}=35$ & $3 / 35$ & $0 / 35$ & $6 / 35$ & $5 / 35$ & $2 / 35$ & $3 / 35$ & $8 / 35$ & $8 / 35$ \\
\hline
\end{tabular}

(-) No gene amplification / act: cytotoxic enterotoxin / asa $_{-}$: hemolysin / ascV: type III secretion system 
Table 2. Antimicrobial susceptibility of Aeromonas spp.

\begin{tabular}{|c|c|c|c|c|c|c|c|c|c|c|}
\hline \multirow{2}{*}{$\begin{array}{l}\text { Drugs } \\
\left(\mu \mathrm{g} \mathrm{mL}^{-1}\right)\end{array}$} & \multirow[b]{2}{*}{ Profile } & \multicolumn{3}{|c|}{ Clinical strains } & \multicolumn{4}{|c|}{ Environmental strains } & MIC50 & MIC90 \\
\hline & & $\begin{array}{l}\text { A. hydrophila } \\
(\mathrm{n}=19)\end{array}$ & $\begin{array}{c}\text { A. veronii bv.sobria } \\
(\mathrm{n}=3)\end{array}$ & $\begin{array}{c}\text { A. caviae } \\
(\mathrm{n}=1)\end{array}$ & $\begin{array}{l}\text { A. hydrophila } \\
(\mathrm{n}=11)\end{array}$ & $\begin{array}{l}\text { A. veronii bv. sobria } \\
(\mathrm{n}=22)\end{array}$ & $\begin{array}{l}\text { A. veronii bv. veronii } \\
(\mathrm{n}=1)\end{array}$ & $\begin{array}{c}\text { A. caviae } \\
(\mathrm{n}=1)\end{array}$ & \multicolumn{2}{|c|}{$\begin{array}{c}\text { Aeromonas spp. } \\
(\mathrm{n}=\mathbf{5 8})\end{array}$} \\
\hline \multirow{3}{*}{ AMC } & $\mathrm{S}$ & - & - & - & $4 / 2-8 / 4(2)$ & $0.5 / 0.25-8 / 4(7)$ & $4 / 2(1)$ & - & \multirow{3}{*}{$32 / 16$} & \multirow{3}{*}{$32 / 16$} \\
\hline & I & $16 / 8(5)$ & $16 / 8(2)$ & $16 / 8(1)$ & $16 / 8(1)$ & $16 / 8(7)$ & - & - & & \\
\hline & $\mathrm{R}$ & $32 / 16(14)$ & $32 / 16(1)$ & - & $32 / 16-64 / 32(8)$ & $32 / 16-64 / 32(8)$ & - & $32 / 16(1)$ & & \\
\hline \multirow{3}{*}{ PTZ } & S & $1 / 4-16 / 4(17)$ & $2 / 4-8 / 4(2)$ & - & $1 / 4-16 / 4(11)$ & $0.5 / 4-16 / 4(20)$ & $0.5 / 4$ & $16 / 4(1)$ & \multirow{3}{*}{$4 / 4$} & \multirow{3}{*}{$64 / 4$} \\
\hline & I & - & - & $64 / 4(1)$ & - & $64 / 4(1)$ & - & - & & \\
\hline & $\mathrm{R}$ & $256 / 4-512 / 4(2)$ & $128 / 4(1)$ & - & - & $128 / 4(1)$ & - & - & & \\
\hline \multirow{3}{*}{ CAZ } & S & $0.25-4(18)$ & $0.25-0.5(3)$ & $0.5(1)$ & $0.25-4(11)$ & $0.125-4(22)$ & $0.125(1)$ & $0.5(1)$ & \multirow{3}{*}{0.75} & \multirow{3}{*}{2.2} \\
\hline & I & - & - & - & - & - & - & - & & \\
\hline & $\mathrm{R}$ & $64(1)$ & - & - & - & - & - & - & & \\
\hline \multirow{3}{*}{ FEP } & S & $0.06-0.5(19)$ & $0.03-0.125(3)$ & $0.25(1)$ & $0.03-0.125(11)$ & $0.06-0.125(22)$ & $0.06(1)$ & $0.06(1)$ & \multirow{3}{*}{0.0925} & \multirow{3}{*}{0.1375} \\
\hline & I & - & - & - & - & - & - & - & & \\
\hline & $\mathrm{R}$ & - & - & - & - & - & - & - & & \\
\hline \multirow{3}{*}{ МЕM } & S & $0.06-2(18)$ & $0.25-1(3)$ & $0.015(1)$ & $0.015-2(11)$ & $0.015-1(22)$ & $0.25(1)$ & $1(1)$ & \multirow{3}{*}{0.25} & \multirow{3}{*}{1} \\
\hline & I & - & - & - & - & - & - & - & & \\
\hline & $\mathrm{R}$ & $16(1)$ & - & - & - & - & - & - & & \\
\hline \multirow{3}{*}{ IPM } & S & $2-4(16)$ & $1-2(3)$ & $0.25(1)$ & $0.125-2(10)$ & $0.06-2(22)$ & $2(1)$ & $1(1)$ & \multirow{3}{*}{2} & \multirow{3}{*}{4} \\
\hline & I & $8(2)$ & - & - & $8(1)$ & - & - & - & & \\
\hline & $\mathrm{R}$ & $32(1)$ & - & - & - & - & - & - & & \\
\hline \multirow{3}{*}{ GN } & S & $1-4(18)$ & $2-4(3)$ & $1(1)$ & $1-4(10)$ & $1-4(18)$ & - & $4(1)$ & \multirow{3}{*}{2} & \multirow{3}{*}{8} \\
\hline & I & $8(1)$ & - & - & $8(1)$ & $8(4)$ & $8(1)$ & & & \\
\hline & $\mathrm{R}$ & - & - & - & - & - & - & & & \\
\hline \multirow{3}{*}{ CIP } & S & $0.002-0.25(18)$ & $0.01-0.08(3)$ & $0.008(1)$ & $0.0005-0.008(11)$ & $0.00025-0.06(22)$ & $0.0005(1)$ & $0.001(1)$ & & \\
\hline & I & - & - & - & - & - & - & - & 0.004 & 0.015 \\
\hline & $\mathrm{R}$ & $8(1)$ & - & - & - & - & - & - & & \\
\hline & S & $0.06 / 1.18-0.25 / 4.75(18)$ & $0.125 / 2.3-0.25 / 4.75(3)$ & $0.25 / 4.75(1)$ & $0.03 / 0.59-0.125 / 2.3(11)$ & $0.06 / 1.18-0.25 / 4.75(22)$ & $0.06 / 1.18(1)$ & $\begin{array}{l}0.06 / 1.18 \\
\quad(1)\end{array}$ & & \\
\hline SXT & I & - & - & - & - & - & - & - & $0.125 / 2.375$ & $0.25 / 4.75$ \\
\hline & $\mathrm{R}$ & $16 / 304(1)$ & - & - & - & - & - & - & & \\
\hline
\end{tabular}

(-) No strains / AMC: amoxicillin-clavulanate / PTZ: piperacillin-tazobactam / CAZ: ceftazidime / FEP: cefepime / MEM: meropenem / IPM: imipenem / CIP: ciprofloxacin / SXT: trimethoprim-sulfamethoxazole / MIC (n) 